\title{
Investigating Historic Cirque Glacier ACtivity in the Grand Tetons National Park
}

\author{
F. Michael Conway $\downarrow$ F. W. CROXEN III \\ DEPARTMENT OF GEOLOGY $\uparrow$ ARIZONA WESTERN COLLEGE $\uparrow$ YUMA \\ HEATHER DAVIS $\downarrow$ DEPARTMENT OF ENVIRONMENTAL SCIENCES \\ NORTHERN ARIZONA UNIVERSITY $\uparrow$-YUMA
}

\begin{abstract}
$\uparrow$ OBJECTIVES
Using GPS-technology, satellite imagery and photographic archives we wanted to document historic 20th Century changes in position, mass, and volume of cirque Glaciers of Grand Teton National Park. Our chief goal is to understand climatic processes impacting small-volume cirque glaciers in continental North America.
\end{abstract}

\section{$\uparrow \quad$ REPORT}

The Teton Range of Grand Teton National Park (GTNP) is home to about a dozen small-volume glaciers nestled in shaded east- or north-facing cirques, including: Falling Ice, Teton, School Room, Skillet, Middle Teton, Moran, Teepee, and Triple glacier. These glaciers date to about 4000 years B.P. and represent post-Pleistocene glaciation of northwestern Wyoming. The Grand Teton cirque glaciers are an important GTNP resource, drawing backcountry visitors each year and providing meltwaters to the upper Snake River Basin in August and September.

From 1929 until the mid-1950's Teton glacier was in retreat (Reed Jr., 1964). Retreat (i.e., mass balance losses) of alpine glaciers is chiefly the result of climate forcing, with a minor contribution attributed to topographic modification of climate (Allen, 1997). From 1954 through 1963, ice thickness at Teton glacier increased to the point that Reed Jr. (1964) forecast a probable advance by the late 1960's. Elder et al. (1994) used data from a single season to evaluate the accumulation gradient of Teton Glacier. Their preliminary results suggest that accumulation at the glacier is greater than expected from local snowfall data. Activity of other GTNP alpine glaciers is undocumented, and potential hazards and hazard assessment are unstudied.

In July 2000, we mapped Teton Glacier and Schoolroom Glacier using global positioning satellite (GPS) receivers. Teton Glacier, located below Grand Teton, is the largest of the Parks cirque glaciers with an areal extent of nearly 310,000 square meters. Schoolroom is the smallest recognized glacier in the Teton Range and has an area of about 8800 square meters. Volumes are poorly constrained because of the absence of robust thickness data.

GPS mapping of Teton Glacier and Schoolroom Glacier was only partially successful. Post processing using base station data from the Idaho National Engineering and Environmental Laboratory, in Idaho Falls, Idaho, provided high quality, one-meter ground-cell resolution data; more than sufficient for our study. However, residual snowfields mantled the snouts of both glaciers, hampering accurate mapping of these crucial areas. We also encountered problems when mapping adjacent to or immediately underneath rockwalls. High arching rock walls corrupted our satellite arrays or otherwise degraded the GPS satellite signal. 
Uncorrupted data, while of excellent quality, provides a less-than-complete map of the ice bodies. We have plans to return in the summer of 2002 to complete mapping using laser rangefinder technology slaved to a GPS receiver. The laser rangefinder has an effective range of 500 -meters and can be deployed atop terminal moraines providing an unobstructed view of the GPS satellite array. In this way, we can map the interface between glacial ice and the rockwall without losing or degrading the satellite signal.

Our efforts to use Landsat-7 Thematic Mapper images to differentiate glacial ice from surrounding snowfields was largely successful. However, ground-cell resolution of the Landsat TM data is a bit coarse at 25 -meters. We are currently trying to merge this data with higher resolution ground-cell data to better resolve ice boundaries. Reseating photographic sites established in 1964 (Reed Jr., 1964) yielded photographs that can be compared with existing photographic archives to quantify positional changes in the snout.

Detailed hazard evaluation is incomplete. Precursory examinations at Teton and Schoolroom Glaciers reveal that hazards that exist are confined to the cirque proper and include: local ice or snow collapse, hidden crevasses, and rockfall from surrounding rockwalls. Glaciers whose snouts extend to the lower lip of the cirque, such as Falling Ice and Triple Glacier, are potential ice collapse sites that could impact areas downslope of the cirque.

\section{LITERATURE CITED}

Allen T.R., 1997, Topographic context of glaciers and perennial snowfields, Glacier National Park, Montana. Geomorphology, v. 21, p. 207-216.

Butler D.R., 1989, Glacial hazards in Glacier National Park, Montana. Physical Geography, V.H. Winston \& Sons, p. 53-71.

Elder K., Fullerton S., and Tonnessen K., 1994, Winter mass balance measurements on Teton Glacier begin to build basis for predicting seasonal melt and runoff. Park Science, v. 14, no. 3, p. 11-13.
Elvidge, C.D., 1988, Vegetation reflectance features in AVIRIS data. In, Proceedings of the sixth Thematic Conference on Remote Sensing of Exploration Geology, ERIM, Houston, TX, p. $169-182$.

Harper J.T., 1993, Glacier terminus fluctuations on Mount Baker, Washington, U.S.A., 19401990, and climatic variations. Arctic and Alpine Research, v. 25, p. 332-340.

Oerlemans J., 1996, Modelling the response of valley glaciers to climatic change. Physics and chemistry of the atmospheres of the Earth and other objects of the Solar System, ed. C. Boutron, Les Editions de Physique, p. 91123.

Pelto, M.S., 1996, Annual net balance of North Cascade glaciers, 1984-94. Journal of Glaciology, v. 42, no. 140 , p. 3-9.

Reed Jr., J.C., 1964, Recent retreat of the Teton Glacier, Grand Teton National Park, Wyoming. U.S. Geological Survey Professional Paper 501-C, p. C147-C151.

Roberts, D.A., Yamaguchi, Y., and Lyon, R.J.P. (1985), Calibration of Airborne imaging spectrometer data to percent reflectance using field spectra measurements. In, Proceedings of the 19th International Symposium on Remote Sensing of the Environment, Ann Arbor, MI, p. 679-688.

Saipano J.J., Harrison W.D. and Echelmeyer K.A., 1998, Elevation, volume and terminus changes of nine glaciers in North America. Journal of Glaciology, v. 44, no. 146, p. 119 135.

Tufnell L., 1984, Glacier Hazards. Longman Group Ltd., London, 97 p.

Ui T., Yamamoto H., and Suzuki-Kamata K., 1986, Characterization of debris avalanche deposits in Japan. Journ. of Volcanology and Geothermal Research, v. 29, p. 231-243.

U.S. National Research Council, 2000, Reconciling observations of Global temperature change. http://books.nap.edu/catalog/9755.html. 
Ventura D.A., Rampini, A., Rabagliati, R., Barbero R.S., 1987, Development of a satellite remote sensing technique for the study of alpine glaciers. Internat. Journ. of Remote Sensing, v. 8, no. 2, p. 203-215.

Williams, Jr., R.S., Hall, D.K. and Benson C.S., 1991, Analysis of glacier facies using satellite techniques. Journal of Glaciology, v. 37 , no. 125 , p. $120-128$. 